\title{
Nationalist environmental problems in Soviet Union
}

\section{London}

Tire Central Committee of the Communist Party of the Soviet Union and the Council of Ministers of the USSR have adopted a resolution launching a longterm USSR state programme for environmental protection and the rational use of natural resources. The programme is to be fully worked out by the end of next year. It will deal in particular with the development of waste-free technologies, the reequipping of existing industrial enterprises and the best siting of new ones, improvement of environmental monitoring service, a drive for better ecological education of management cadres and a public information programme, studies of the cost-efficiency of environmental protection measures, and the monitoring of "particularly crucial" installations such as high dams and mud-slide traps.

The Soviet public, thanks to glasnost, is well aware of the need for such measures. Yet, ironically, virtually all the environmental initiatives of the past two years (which the new programme is intended to answer at the All-Union level) have been triggered by national sentiments. Ukrainians have launched protests against the planned Danube-Dnieper canal and the proposed nuclear power station at Chyhyryn. Latvians, Byelorussians and Lithuanians have successfully halted construction work on the planned Daugavpils hydroelectric station. The Tadjik Academy of Sciences says that a new dam (superfluous to the power needs of the Tadjik SSR) in that highly seismic area would prove a 'sword of Damocles" above the republic's capital Dushanbe.

In the wake of the nationalist disturbances in Kazakhstan last autumn, citizens of Alma-Ata have reminded each other that in 1973 the city narrowly escaped being wiped out by a mud-slide because Moscow planners overruled local experts in the choice of a design for mudretention installations.

The environmental needs of the fifteen union republics sometimes come into conflict. The seven Russian writers collectively known as the Villagers, whose works proclaim traditional Russian values and life-styles, campaigned vigorously for the cancellation of the southward-diversion of Siberia's north-flowing rivers. But to the inhabitants of Soviet Central Asia, the decision to halt work on the diversion was most unwelcome, as without the Siberian water, the Aral Sea, whose fecder-rivers have been dangerously depleted by irrigation works, is in danger of drying up completely. The Uzbek Union of Writers accordingly established a 'public committee' to save the Aral, and continues to urge that it is impossible to rescue the sea without the introduction of water from elsewhere. (The official Moscow line is that the locals must learn to manage their existing resources more efficiently.)

Soviet environmental conflicts, however, are not simply a matter of local heroes versus Moscow villains. Some local worthies have been reluctant to join in the ecological debate. The campaign of the Georgian writers against the Caucasian Mountain Railway was launched in April by the quasi-dissident Akaki Bakradze, but only after the party secretary of the republic had publicly criticized Georgian failure to follow the example of the Villagers.

In Armenia, environmental lobbying began as early as 1985 , with attacks by leading members of the Armenian Academy of Sciences on environmental threats ranging from the emissions of chemical plants to a nuclear spent-fuel dump to serve the entire Caucasus. On the basis of the scientists' findings, in March 1986, 350 Armenian intellectuals signed an open letter to Mikhail Gorbachev, protesting that environmental pollution in the republic had now reached horrific proportions.

Nothing, however, was done, until in June 1987, the Moscow Literaturnaya Gazeta published an article by Armenian journalist Zori Balayan, "Is Armenia on the brink of an ecological disaster?" As a result of this article, an expert commission was sent from Moscow, which, after a twoweek stay, produced a package of recommendations for the closure and relocation of chemical plants and the curtailment of the nuclear energy programme virtually identical with that proposed in the 1986 open letter. The local authorities, however, seem unwilling to take action, so that on at least two occasions in the past few weeks protesters, including party officials, have gathered outside the Nairit chemical installations, one of the chief offenders.

Perhaps an even more disturbing case was reported in Kirgizia last month - a cement works $2 \mathrm{~km}$ from Lake Issyk Kul, which was closed down after prolonged local lobbying, was opened again after a few hours on the direct orders of the Kirgiz Minister of the Construction Materials Industry and of the provincial party secretary.

\section{India's electronics companies drive back foreign competition}

\section{New Delhi}

INIIA is succesfully driving back foreign electronics companies from some of its home markets and may soon emerge as an international competitor in its own right.

The first signs that India could produce its own mass-market electronic technology came when the governmentowned Semiconductor Complex Ltd of Chandigarh launched a digital wristwatch in July. More than a million have been sold and the trade in smuggled watches is coming to an end.

Now, successes are coming in two other areas: digital telephone switching equipment and large-scale integrated circuit chips.

Telephone exchanges are being designed at the Centre for Development of Telematics (C-DOT), the creation of Sam Pitroda, an expatriate Indian who was a successful entrepreneur in the United States. Three years after setting up, and with an expenditure of just $\$ 25$ million, C-DOT succeeded in developing a family of digital switching systems for which most components can be manufactured locally.

According to Pitroda, the technology is tailored to the needs of developing countries, which lack air conditioning and have power supply problems, dusty environ- ments and unskilled manpower. The technology is also tailored to India's low telephone density - just 3.5 million telephones for a population of 700 million.

Large-scale integrated circuit chips are already being exported to Far Eastern markets. They come from Semiconductor Complex Ltd, which soon expects to export a million chips a month. Its first products were 5-micron scale - still primitive by the 2-micron standards needed for standard 256K RAMs - but SCL's 200 engineers have subsequently developed 3- and 2-micron technologies in-house. Next year the company will introduce 1.25-micron technology and it has plans for building an electron-beam facility with money from the World Bank so as to tackle sub-micron designs.

SCL's marketing manager, P.S. Mankhad, says the aim is to counter the competition from international giants "with simple and standardized products at low price". Given India's plentiful supply of inexpensive, skilled manpower, "we can compete with the United States and Japan," he says. Demand is expected to rise sharply, and SCL's chairman $\mathrm{Mr}$ Virendra Mohan believes India will be exporting chips to the value of a thousand million dollars worth of chips a year in the early 1990 s.
K. S. Jayaraman 